\title{
BECERi ÖĞRENIM REHBERI VE DEĞERLENDIRME REHBERI HAZIRLAMA: HPV-DNA NUMUNE ALMA ÖRNEĞi
}

\author{
SKILL LEARNING GUIDE AND ASSESSMENT GUIDE PREPARATION: \\ HPV-DNA SAMPLING
}

\author{
Aysel BAŞER, Nilüfer DEMIRAL YILMAZ, Hatice ŞAHIN
}

EÜTF Tıp Eğitimi Anabilim Dalı

\begin{abstract}
Cite this article as: Başer A, Yılmaz Demiral N, Şahin H. Skill Learning Guide And Assessment Guide Preparation: Hpv-Dna Sampling. Med J SDU 2019; 26(4): 452-457.
\end{abstract}

\section{Öz}

\section{Amaç}

Kadınlarda serviks kanseri önemli bir sağlık sorunudur. Serviks kanseri tarama yöntemleri invazif kanser insidansını ve mortalitesini azalttığı düşünülen az sayıdaki tarama yönteminden biridir. Sağlık Bakanlığı son dört yıldır 30-65 yaş kadınlarda HPV numune alma veya pap-smear ile tarama başlatmıştır.

Ulusal Çekirdek Eğitim Programı 2014 (UÇEP 2014) her tıp fakültesi mezunun nitelikli bir hekim olması için sahip olması gereken temel gerekliliklere/yeterliklere yönelik olan ve tıp eğitimi süresince her bir öğrencinin alması gereken asgari eğitimin içeriğini tanımlamaktadır (1). UÇEP 2014'te koruyucu sağlık hizmetleri başlıkları incelendiğinde serviks kanseri taraması da yer almaktadır (1). Mezuniyet öncesi dönemde tıp öğrencileri pap-smear tarama ile ilgili beceriyi öğrenmelerine rağmen HPV ile ilgili numune alma konusunda herhangi bir beceri eğitimi almamakta ve değerlendirme yapılmamaktadır.

\section{Gereç ve Yöntem}

Çalışmada Sağlık Bakanlığı'nın serviks kanseri tarama programında geliştirdiği HPV DNA numune alma şeması ve pap-smear alma becerisi eğitim kılavuzu temel alınmıştır. UÇEP'te yer alan 'hasta ile iletişim, hastayı hazırlama, sterilizasyona uyum, HPV DNA ve pap-smear numune alma, atık yönetimi ve numune saklanması, vajinal muayene' başlıkları göz önünde bulundurularak 40 maddeden taslak eğitim rehberi oluşturulmuştur (1). Lawshe tekniği kullanılarak uzman görüşleri doğrultusunda farklı meslek gruplarında (aile hekimliği uzmanı, diş hekimliği, kanser tarama merkezi hekimi, ebe ve hemşire) pilot çalışması yapılarak nihai eğitim rehberi oluşturulmuştur. Mesleksel beceri eğitim rehberi oluşturulduktan sonra uzman görüşüne başvurularak değerlendirme rehberinde hasta ile iletişim, hastayı hazırlama, sterilizasyona uyum, numune alma, atık yönetimi ve numune saklanması başlıklarının bu becerinin sınanmasında kullanılması öngörülmüştür.

\section{Bulgular}

Geliştirilen HPV DNA numune alma beceri eğitim rehberi Lawshe tekniği kullanılarak KGO \%100 ile uzman görüşleri doğrultusunda 33 maddeden oluşturulmuştur. Eğgitim rehberinin ölçeklemesinde 'geliştirilmesi gerekir, henüz olgunlaşmamış, yeterli, iyi seviyede, ustalaşmış' basamakları kullanılmıştır. HPV DNA numune alma becerisini değerlendirme amacıyla 20 maddeden oluşan ve 5'li Likert ölçeği ile puanlanan bir değerlendirme rehberi geliştirilmiştir.

İletişim kurulacak yazar/Corresponding author: aysel.akpinar@gmail.com

Müracaat tarihi/Application Date: 06.11.2018 - Kabul tarihi/Accepted Date: 09.11.2018

Available online at http://dergipark.gov.tr/sdutfd

Makaleye http://dergipark.gov.tr/sdutfd web sayfasından ulaşılabilir. 


\section{Sonuç}

Ülkemizde tıp fakültesinden mezun olan hekim, uzmanlık eğitimine başlamadığı sürece çoğunlukla Sağlık Bakanlığı'na bağlı birinci basamak sağlık hizmetlerinde çalışmaktadır. Bu nedenle çalışma koşulları ile uyumlu ve UÇEP 2014'te tanımlanan beceri başlıklarının tıp fakültelerinde yeterliliği sağlayacak düzeyde öğretilmesi ve geliştirilen değerlendirme rehberi eşliğinde sınanması esastır. Böylece beceri uygulamaları konusunda yeterli hekimler çalışma hayatında da özgüvenli, başarılı ve diğer sağlık personellerine de öncü olacaktır.

Anahtar Kelimeler:HPV-DNA Numune Alma, Öğrenim Rehberi, Değerlendirme Rehberi, Ulusal ÇEP 2014,

\section{Abstract}

\section{Objective}

Cervical cancer is a major health problem in women. Cervical cancer screening methods are one of the few screening methods considered to decrease the incidence and mortality of invasive cancer. The Ministry of Health has launched HPV sampling or screening with pap-smear in women aged 30-65 for the last four years.

The National Core Curriculum 2014 (NCC 2014) defines the content of the minimum training required for each student during the medical education (1). In 2015 , cervical cancer screening is included in the review of preventive health services (1). Although medical students learn the skills related to pap-smear screening in the undergraduation period, they do not receive any skills training on HPV and do not make any evaluation.

\section{Materials and Methods}

The study was based on the HPV DNA sampling scheme developed by the Ministry of Health in the cervical cancer screening program and the pap-smear training skills guide. A draft training guide was prepared from

\section{Giriş}

Tıp eğitimi bilişsel, duyuşsal ve psikomotor öğrenme alanlarını kapsayan bir eğitim sistemidir. Tıpta öğretme ve öğrenmenin temel dayanağı ise klinik öğretimdir. Bir klinik beceri eğitiminde amaç; belirli bir işlem veya etkinlik için gerekli olan bilgi, tutum ve beceriyi kazandırmaktır (2).

Beceri eğitiminin en geleneksel şekli hastalar üzerinde yapılan eğitimdir ancak son günlerde hasta ve ça-
40 items by considering the headings of 'communication with the patient, patient preparation, sterilization compliance, HPV DNA and pap-smear sampling, waste management and sample storage, vaginal examination '(1). In accordance with the expert opinions of the Lawshe technique, a pilot study was conducted in different occupational groups (family medicine specialist, dentist, cancer screening center doctor, midwife and nurse) and a final training guide was created. After the preparation of the professional skills guide, it is envisaged to use the expert opinion in the evaluation guideline to communicate with the patient, prepare for the patient, adapt to sterilization, sampling, waste management and storage of samples.

\section{Results}

Developed HPV DNA sampling skill training guide using Lawshe technique SVR $100 \%$ was formed by 33 items according to expert opinions. In the scaling of the training guideline, mış needs to be developed, yet immature, sufficient, good level, mastered esinde steps have been used. In order to evaluate HPV DNA sampling ability, an evaluation guideline composed of 20 items and scored with 5-point Likert scale was developed.

\section{Conclusions}

The physician graduated from the medical faculty in our country works mostly in primary health care services under the Ministry of Health as long as it does not begin to specialization training. For this reason, it is essential that the skill titles that are compatible with the working conditions and defined in NCC 2014 should be taught in a level that will ensure competence in the medical faculties and in the light of the evaluation guide developed. Thus, physicians who are competent about their skill applications will be confident, successful and pioneer in other health personel in their working life.

Keywords: HPV-DNA Sampling, Training Guide, Assessment Guide, National Core Curricullum 2014,

Iışan güvenliği kavramları önem kazandığı için beceri eğitimlerinde yeni yöntem arayışını zorunlu kılmıştır. Günümüzde kabul edilen yaklaşım tanımlanan belirlenen yeterlik alanları ve düzeyleri üzerinden yapılandırımış, öğrenenin sürece aktif katılımının sağlandığı, öğrenme ortamların da becerilerin rehber eşliğinde, maket üzerinde kazandırılmasıyla sağlanmaktadır. Bu aşamada yeni öğrenmeye başlayanlar için kaygı yaratmayan güvenli ortamlar oluşturulmuş olur. Bu ortamlar gerçek ortama yakın olmasına rağmen bağlamdan uzak karmaşıklık ve sorun içermeyen, beceri- 
nin daha çok teknik yönünü ortaya koyan ortamlar ve araç gereçlerdir. Beceri eğitimlerin de yapılan gözlem ve değerlendirme ışığında tekrarlanan amaçlı uygulamalar sonrasında gerçek hasta ve gerçek ortamda pekiştirilmesi sonrasında beklenen yeterliklere ve yetkinliğe ulaşmış oluruz (3).

Becerilerin öğrenilmesi, öğretilmesi ve değerlendirilmesi aşamasında uygulanan yöntem, teknik ve stratejinin seçilmesinde öğrenme kuramlarının büyük katkısı vardır. Beceri eğitimlerinin geliştirilmesinde temel rol bilişsel, davranışçı ve yapılandırmacı kuramlara düşer (4). Beceri eğitimlerinde basamaklandırılmış rehberlerin kullanımı, geribildirim verilmesi, olumlu pekiştireç uygulamaları ile eğitimlerin yürütülmesi davranışçı yaklaşımların eğitimdeki yansımalarıdır.

Eğitim öncesinde beceri eğitimlerinin temelini oluşturan konuların tartışılması, ön hazırlık safhası, akıl yürütme oturumlarında önceki bilgilerle ilişkilendirilmesi bilişsel kuramın eğitimdeki etkileri olarak görülebilir. Beceri eğitimi verilme aşamasında öğretenin beceriyi göstermesi, rol modelliği, öğrenenlerin eğitici ve akran destekleri ile beceriyi edinmesi sosyal bilişsel kurama örnek olarak söylenebilir. Eğitim öncesinde öğrenenlerin içerik konusundaki bilgilerinin ortaya konması, karmaşık, anlaşılması zor kavramların ortaya konması, tartışılması, öğrenenlerin bu deneyimdeki farklı algı ve performans nedenlerini ortaya konması yapılandırmacılığın eğitimdeki etkileri olarak düşünülebilir (3).

Klinik beceri eğitiminde hizmetin kalitesini artırmak, katılımcıların performansını objektif bir şekilde değerlendirmek için eğitimin standardize edilmesi ve insan üzerinde ilk deneyim yapılmadan önce insancıl bir eğitim tekniği kullanmak gereklidir. Eğitim zamanını kısaltmak, öğrenmeyi kolaylaştırmak ve hastanın maruz kalacağı riskleri en aza indirmek için işlemleri hasta üzerinde denemeden önce beceri eğitimi eğitimlerine katılmak gereklidir $(3,5,6)$.

Türkiye' de temel eğitim becerilerini tanımlamak için tıp eğitiminde herhangi bir ortak konsessus oluşturulmamıştır ve mezuniyet öncesi her tıp fakültesinin farkı bir beceri eğitim programı mevcuttur. Tıp fakülteleri arasındaki bu farklılığın en belirgin olduğu alan sahada jinekolojik muayene esnasında belirginleşmiştir. Eğitim programı farklı olan fakültelerden mezun olan tıp öğrencileri jinekolojik muayene yapmadan mezun olabilir ve hekim olarak uygulama yapmak zorunda kalması ile sonuçlanabilir (7).

Sağlık Bakanlığının 2014 yılından itibaren rahim ağzı kanser tarama programı çerçevesinde; Aile Sağlığı Merkezinde (ASM), Toplum Sağlığı Merke-
zinde(TSM), Ana Çocuk Sağlığı ve Aile Planlaması (AÇSAP) ve Kanser Erken Teşhis Tarama ve Eğitim (KETEM) merkezinde çalışan tüm hekim, hemşire, ebe ve sağlık memurları tarafından hedef nüfusa, yani kadınlarda 30 yaşında başlayan ve 65 yaşında biten toplum tabanlı bir tarama yapılmaktadır (8). Serviks kanserinin taranmasındaki temel amaç; ülke çapında oluşturulacak ulusal bir tarama programını hedef popülasyona uygulayarak, servikal patolojileri henüz premalign veya erken evrede iken tespit etmek, etkin ve basit yöntemlerle tedavi etmek suretiyle de invaziv kanser sıklığını, buna bağlı morbidite ve mortaliteyi düşürerek olası karmaşık ve pahalı tedavileri önlemektir (8).

Tarama için servikal sitolojiye ek olarak HPV DNA testini kullanırken klinisyenlere ve hastalara rehberlik etmeye yardımcı olmak için ABD'de gerçekleştirilen bir çalıştay da devam eden tarama çalışmalarından elde edilen literatür taraması, uzman görüşü ve yayınlanmamış sonuçlara dayalı olarak 30 yaş ve üzeri kadınlarda yapılan taramalarda servikal sitolojiye HPV DNA testinin eklenmesi şeklinde karar verilmiştir (9).

Ülkemizin altyapısı ve olanakları göz önüne alındığında ideal yöntem beş yılda bir uygulanacak HPV testi veya yılda bir uygulanması gereken Pap-smear testi ile taramadır. Hedef, kadınlarda 30 yaşında başlayan ve 65 yaşında biten toplum tabanlı taramadır. Taranacak popülasyon, aile hekimlerine kayıtlı bireyler esas alınarak tanımlanmalıdır (8). HPV-DNA ve Pap-smear testi geliştirilecek davet yöntemleriyle her beş yılda bir tekrarlanır. Son iki HPV-DNA testi Pap-smear testi negatif olan 65 yaşındaki kadınlarda tarama kesilmelidir. HPV-DNA testi, uygun şekilde eğitilmiş sağlık sağlayıcıları ve gerekli malzeme ve ekipmana sahip herhangi bir sağlık kuruluşunda gerçekleştirilebilir (10).

Mezuniyet öncesi tıp eğitiminin sonunda mezun olan hekimin nitelikli bir sağlık hizmeti sunabilmesi, karşı karşıya olduğu sağlıkla ilgili güncel durumları etkin bir şekilde anlayabilmesi, haberdar olması değerlendirebilmesi ve yönetebilmesi, sağlık alanında üstlendiği görevleri nitelikli bir şekilde yerine getirebilmesi için standardize bir eğitim programına ihtiyacı vardır. Bu tarama programından yola çıkarak Tıp fakültelerinin eğitim programlarına HPV-DNA numune alma beceri eğitimini entegre etmeleri gerekmektedir.

Bu eğitimi Ulusal ÇEP 2014 içerisinde tanımlanan mezun yeterliklere bakarak tanımlamak istersek; mezuniyet sonrası hekimlerin 1. basamak koruyucu sağlık hizmetlerinin tamamına yakınını yapması beklenmektedir. Ulusal ÇEP 2014 içerisinde temel hekimlik uygulamaları analiz edildiğinde HPV-DNA ile ilişkili 
olan ve öğrenme düzeyi üç olan başlıklar "mikroskopik inceleme için boyalı-boyasız preparat hazırlayabilme ve inceleme yapabilme, tarama ve tanısal amaçlı inceleme sonuçlarını yorumlayabilme, hastadan biyolojik örnek alabilme, vajinal ve servikal örnek alabilme ve toplumda sağlıkla ilgili sorunları epidemiyolojik yöntemler kullanarak saptayabilme ve çözüm yollarını ortaya koyabilmedir. "HPV-DNA ile ilişkili olan ve öğrenme düzeyi dört olan başlıklar "jinekolojik muayene, biyolojik materyalle çalışma ilkelerini uygulayabilme, laboratuvar inceleme için istek formunu doldurabilme, laboratuvar örneğini uygun koşullarda alabilme ve laboratuvara ulaştırabilme, el yıkama ve aile planlaması danışmanlığı yapabilmedir." (1).

Bu çalışmanın amacı mezuniyet öncesi tıp eğitiminde HPV DNA numune alma becerisini kazandırmak için mesleksel beceri eğitim rehberi ve değerlendirmede kullanılacak bir ölçme aracının geliştirilmesidir.

\section{Gereç ve Yöntem}

2016-2017 yılları arasında 14 haftalık Ege Üniversitesi Tıp Fakültesi Tıp Eğitimi Anabilim Dalı doktora eğitim programı mesleksel beceri dersi kapsamında beceri öğrenim rehberi ve değerlendirme rehberi geliştirilmiştir. Sağlık Bakanlığı'nın serviks kanseri tarama programı kapsamındaki HPV DNA numune alma şeması ve pap-smear alma becerisi eğitim kılavuzu temel alınmıştır (8) (11). Ayrıca UÇEP'te yer alan 'hasta ile iletişim, hastayı hazırlama, sterilizasyona uyum, HPV DNA ve pap-smear numune alma, atık yönetimi ve numune saklanması, vajinal muayene' başlıkları göz önünde bulundurularak 40 maddelik taslak eğitim rehberi oluşturulmuştur (1). Sonrasında, taslak eğitim rehberinin kapsam geçerliği için uzman görüşü alınmıştır. Maddelerin her birinin kapsam geçerliliği için Lawshe tekniği kullanılmıştır. İki Ege Üniversitesi Tıp Fakültesi Tıp Eğitimi AD öğretim üyesi, iki Aile Hekimliği uzmanı ve bir Tıp Eğitimi doktora öğrencisi olmak üzere beş adet uzman görüşüne başvurulmuştur. Uzmanların görüşleri; öğrenim rehberinde yer alması düşünülen her bir maddenin kapsam geçerliliği Lawshe tekniği ile analiz edilerek (12) yedi madde çıkarılmış ve madde sayısı 33'e indirilmiştir. Madde sayıları netleştikten sonra sıralama, dilbilgisi ve başlık konularında düzenleme yapılarak tam uzlaşma sağlanmıştır. Uzman görüşlerine ilişkin veri analizi bulgular bölümünde ayrıntılı olarak verilmiştir.

Uzman görüşleri doğrultusunda revize edilen taslak eğitim rehberinin 2016-2017'de farklı meslek gruplarında (aile hekimliği uzmanı, kanser tarama merkezi hekimi, diş hekimi, ebe ve hemşire) pilot uygulaması öncelikle eğitici tarafından maket üzerinde rehber kullanılarak uygulama yapılmış ve sonrasında öğrenen- lerin yapması istenilmiştir. Pilot uygulama sonrasında maddelerin sıralamasında yer değişikliği ve anlam bütünlüğü sağlanarak nihai eğitim rehberi oluşturulmuştur. (Resim 1)

HPV DNA numune alma klinik beceri şeklinde sınıflandırıldığı için objektif yapılandırılmış bir değerlendirme yöntemi ile değerlendirilmelidir. Bu değerlendirme, değerlendiren kişinin kişisel yargılarına dayanan geleneksel yönteme göre daha geçerli, güvenilir ve pratiktir. Ulusal ÇEP 2014 öğrenim hedeflerine, Sağlık Bakanlığı'nın serviks kanseri tarama programında geliştirdiği HPV DNA numune alma ve pap-smear alma becerisi eğitim rehberine dayanılarak değerlendirme rehberi geliştirilmiştir. Uzman görüşüne dayanılarak değerlendirme rehberinde hasta ile iletişim, hastayı hazırlama, sterilizasyona uyum, numune alma, atık yönetimi ve numune saklanması başlıklarının bu becerinin sınanmasında kullanılması öngörülmüştür.

HPV DNA numune alma becerisini değerlendirme amacıyla 20 maddeden oluşan ve 5'li Likert ölçeği ile puanlanan bir değerlendirme rehberi geliştirilmiştir. (Resim 2) Öğrencinin bu beceriden yeterlilik alabilmesi için değerlendirme rehberine göre 100 puan üzerinden en az 60 puan alması gereklidir. Ancak değerlendirme rehberinde üç başlık baraj niteliğindedir. Öğrenci baraj niteliğindeki başlıkların tamamından 3 ve üzerinde puan almalıdır. Bu başlıklarda yaşanacak herhangi bir sorun yetersizlik alması şeklinde yorumlanacaktır.

\section{Bulgular}

2016-2017 yılları arasında 14 haftalık bir dönemde HPV-DNA numune alma beceri öğrenim rehberi ve değerlendirme rehberi hazırlanarak tam uzlaşma sağlanmıştır. Illk olarak beceri öğrenim rehberi oluşturmak için madde havuzunun literatür taraması yapılmış ve maddeler oluşturulmuştur. Geliştirilen HPV DNA numune alma beceri eğitim rehberi uzman görüşleri doğrultusunda lawshe tekniği kullanılarak her bir maddenin "Kapsam Geçerliliği Oranı" (KGO) hesaplanmıştır. 40 maddenin KGO \%79 olarak gelmiştir. Lawshe tekniğine göre beş uzman görüşünün KGO \%99 üzerinde olması halinde maddenin geçerliliğinden söz edilebildiği için bazı maddeler düzenlenerek ve yedi maddesi çıkarılarak 33 maddeye indirgenmiştir. 33 maddenin KGO \%100 olarak gelmiştir (12). Eğitim rehberinin ölçeklemesinde 'geliştirilmesi gerekir, henüz olgunlaşmamış, yeterli, iyi seviyede, ustalaşmış' basamakları kullanılmıştır.

HPV DNA numune alma becerisini değerlendirme amacıyla 20 maddeden oluşan ve 5'li Likert ölçeği 
Resim 1: Mesleksel Beceri Öğrenim Rehberi HPV DNA Numune Alma Becerisi

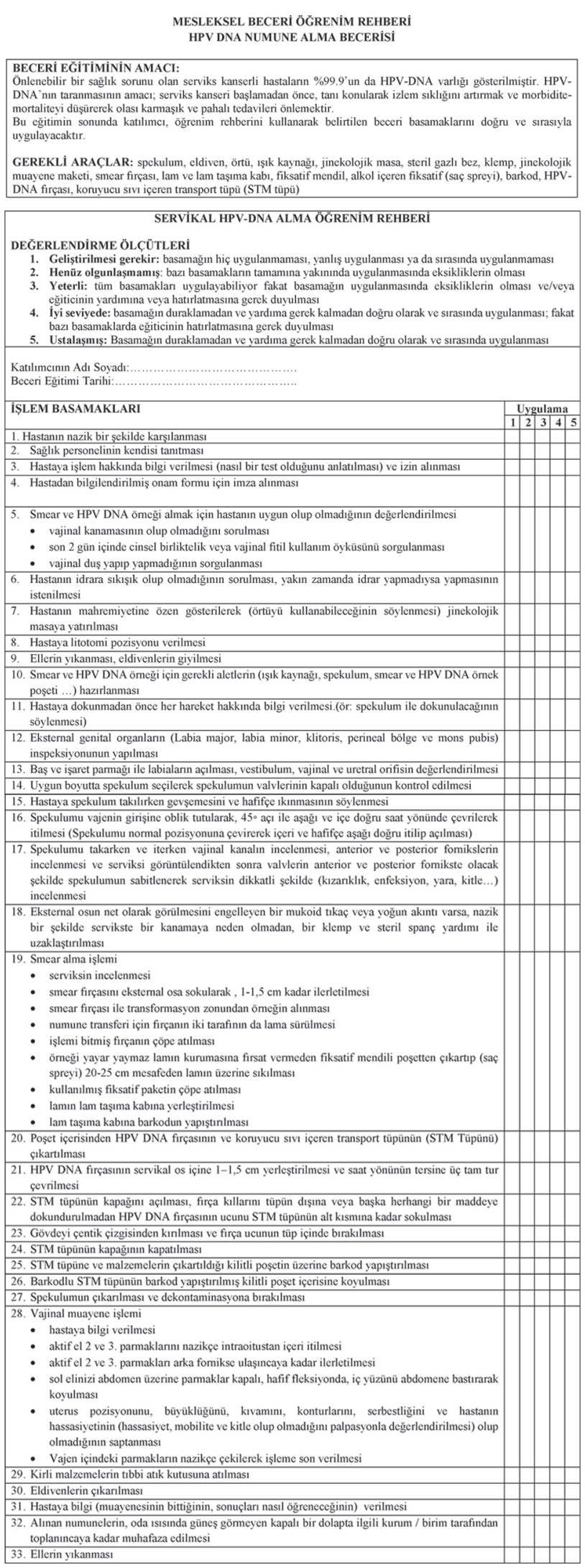

Resim 2: Mesleksel Beceri Öğrenim Rehberi HPV DNA Numune Alma Becerisi Değerlendirme Rehberi

\author{
MESLEKSEL BECERI ÖĞRENIM REHBERI \\ HPV DNA NUMUNE ALMA BECERISI DEĞERLENDIRME REHBERI
}

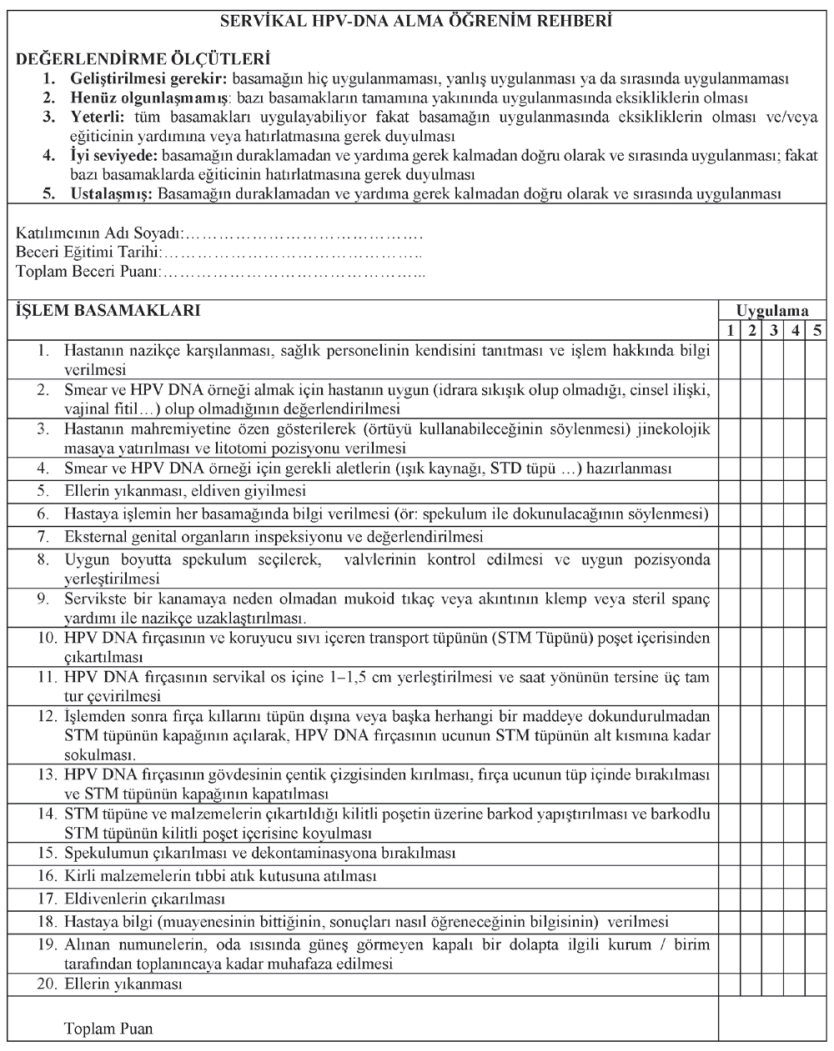

ile puanlanan bir değerlendirme rehberi geliştirilmiştir. Geliștirilen HPV DNA numune alma becerisini değerlendirme rehberi uzman görüşleri doğrultusunda lawshe tekniği kullanılarak her bir maddenin "Kapsam Geçerliliği Oranı" (KGO) hesaplanmıştır. 20 maddenin KGO \%90 olarak gelmiștir. Lawshe tekniğine göre beş uzman görüşünün KGO \%99 üzerinde olması halinde maddenin geçerliliğinden söz edilebildiği için bazı maddeler düzenlenerek tekrar uzman görüşü alınmıştır. 20 maddenin KGO \%100 olarak gelmiştir (12). Eğitim rehberinin değerlendirilmesinde 'geliştirilmesi gerekir, henüz olgunlașmamış, yeterli, iyi seviyede, ustalaşmış' basamakları kullanıımıştır.

\section{Sonuç}

Ülkemizde tıp fakültesinden mezun olan hekim, uzmanlık eğitimine başlamadığı sürece çoğunlukla Sağlık Bakanlığı'na bağlı birinci basamak sağlık hizmetlerinde çalışmaktadır. Hekimlerin mezuniyetlerinde beceriler konusunda yeterli olmaları Sağlık Bakanlığı'nın yürüttüğü tarama programlarında çalışırken de başarılı olmalarını sağlayacaktır. Sağlık Bakanlığı'nın yürüttüğü tarama programlarında çalışırken başarılı 
olmalarını sağlamak için mesleki becerilerinin standardize edilmesi ve diğer sağlık personeline de önderlik etmesi gerekmektedir. Böylece beceri uygulamaları konusunda yeterli hekimler çalışma hayatında da özgüvenli, başarılı ve diğer sağlık personeline de öncü olacaktır. Bu nedenle çalışma koşulları ile uyumlu ve UÇEP 2014'te tanımlanan beceri başlıklarının tıp fakültelerinde yeterliliği sağlayacak düzeyde öğretilmesi ve geliştirilen rehberlerin, değerlendirme rehberleri eşliğinde sınanması esastır.

\section{Eğitimin Uygulanması İle İlgili Bir Öneri}

HPV DNA numune alma beceri eğitimi Aile Sağlığı Merkezinde (ASM), Toplum Sağlığı Merkezinde(TSM), Ana Çocuk Sağlığı ve Aile Planlaması (AÇSAP) ve Kanser Erken Teşhis Tarama ve Eğitim (KETEM) merkezinde saha çalışması esnasında intörn doktorlara eğitici hekim ve sağlık personeli tarafından beceri eğitimi verilir. Beceri eğitimi; eğitici tarafından tanıtımı, amacı ve işlemin nasıl yapılacağının gösterilmesinden sonra eğitime katılan kişinin işlemi en az bir kez maket üzerinde yapması, 3 gerçek hastadan HPV-DNA numune alınması ve geribildirim verilmesi şeklinde uygulanır.

Eğitimcinin (koç) gruba uygulamayı neden yaptığımız ile ilgili bilgi vermesi, anlaşılmayan, karmaşık konulara değinilmesi, karmaşık kavramlar üzerinden tartışma yapılması, ardından uygulamanın nasıl yapıldığı ile ilgili bilgi vermesi, beceri rehberinin gözden geçirilmesi, eğiticinin uygulamayı maket üzerinde nasıl yapılacağını göstermesi (orta gerçeklikli simulatör), her öğrenenin rehbere göre uygulamayı tekrarlaması şeklinde yapılarak bilişsel, davranışçı ve yapılandırmacı kuramlara dayanarak bir eğitim programı geliştirilir. Öğrenen beceri eğitimini uygularken diğer bir öğrenenin rehberden basamakları okunması istenerek hem diğer öğrenenlerin hem de uygulayan öğrenenin daha kolay takip etmesi sağlanır. Bu yöntemde bütün-parça-bütün yaklaşımı kullanılır. Öğrenenin uygulama esnasında ya da daha sonrasında eğitici tarafından geribildirim yapılır. Doğru uygulamalara olumlu pekiştireç yanlış uygulamalar da düzeltme imkanı sağlanır. Daha sonra ikili gruplar halinde her öğrenen diğer öğreneni değerlendirerek becerilerin kalıcılığını artırır.

Hazırlanmış bir değerlendirme rehberi ile eğitimi veren kişi tarafından değerlendirmeye tabi tutulurlar. İlk değerlendirme maket üzerinde ve değerlendirme sonucu başarılı olduğu takdirde 3 gerçek hastadan HPV DNA numune alması sağlanarak ve değerlendirme rehberi kullanılarak, beceri eğitimi sonunda bir sertifika ile sonlandırılır.

\section{Kaynaklar}

1. Ulusal ÇEP 2014. (tarih yok). Ulusal Çekirdek Eğitim Programı. Yükseköğretim Kurulu Genel Kurulu;. http://www.yok.gov.tr/ documents/10279/38058561/tip fakultesi cep.pdf adresinden alındı

2. Amin, Z., \& Eng , K. (2006). Basics in medical education. . Singapore: World Scientific.

3. Elçin, M., \& Odabașı, O. (2016). Beceri Eğitimi. i, \& i. Sayek içinde, Tıp Eğiticisi El Kitabı (s. 179-193). Ankara: Güneş Tıp Kitabevi.

4. Ertmer, P. \&. (1993). Behaviorism, Cognitivism, Constructivism: Comparing critical features from an instructional design perspective. Performance Improvement Quarterly,, 6(4), 50-72.

5. Sullivan, R., Magarick, R., Bergthold, G., Blouse, A., \& Mclntosh, N. (1999). Tıp eğitimcileri için eğitim becerileri rehberi. (Ş. Özvarış, Dü.) Ankara: Hacettepe Halk Sağlığı Vakfı.

6. Vogel, D. \&. (2016). Basic practical skills teaching and learning in undergraduate medical education-a review on methodological evidence. . GMS journal for medical education,, 433.

7. Abraham, S. (1998). Gynaecological examination: a teaching package integrating assessment with learning. Medical education, , 32(1), 79-81.

8. Serviks Kanseri Tarama Programı Ulusal Standartları. (2018, Şubat). T.C. Sağlık Bakanlığı Kanser Daire Başkanlığı: https://hsgm.saglik.gov.tr/tr/kanser-tarama-standartlari/listesi/483-serviks-kanseri-tarama-program\%C4\%B1-ulusal-standartlar\%C4\%B1.html adresinden alındı

9. Wright, T. C. (2004). Interim guidance for the use of human papillomavirus DNA testing as an adjunct to cervical cytology for screening. Obstetrics \& Gynecology, 103(2), 304-309.

10. Singh, P. K. (2017). Training of health staff in VIA, HPV detection test and cryotherapy-Trainees' handbook. WHO.

11. T.C. Sağlık Bakanlığı. (2014). Serviks Kanseri Tarama Programı Ulusal Standartları. Halk Sağlığı Genel Müdürlüğü Kanser Dairesi Başkanlığı: https://hsgm.saglik.gov.tr/tr/kanser-tarama-standartlari/listesi/483-serviks-kanseri-tarama-program\%C4\%B1-ulusal-standartlar\%C4\%B1.html adresinden alındı

12. Lawshe, C. (1975). A quantitative approach to content validity 1. 28(4),. Personnel psychology,, 28(4), 563-575. 